\title{
FILSAFAT PENDIDIKAN KI HAJAR DEWANTARA (TOKOH TIMUR)
}

\author{
I Made Sugiarta ${ }^{1}$, Ida Bagus Putu Mardana ${ }^{2}$, Agus Adiarta ${ }^{3}$, I Wayan Artanayasa ${ }^{4}$ \\ ${ }_{1}^{1}$ Pendidikan Matematika, Universitas Pendidikan Ganesha Singaraja, Indonesia \\ ${ }^{2}$ Pendidikan Fisika, Universitas Pendidikan Ganesha Singaraja, Indonesia \\ 3 Pendidikan Teknik Elektro, Universitas Pendidikan Ganesha Singaraja, Indonesia \\ ${ }^{4}$ Pendidikan Jasmani, Kesehatan dan Rekreasi, Universitas Pendidikan Ganesha Singaraja, \\ Indonesia \\ E-mail:made.sugiarta@undiksha.ac.id1',putu.mardana@undiksha.ac.id², \\ agus.adiarta@undiksha.ac.id ${ }^{3}$, wayan.artanayasa@undiksha.ac.id ${ }^{4}$
}

\begin{abstract}
Abstrak
Gagasan-gagasan filosofis Ki Hajar Dewantara telah menjadi pondasi yang cukup kokoh dalam praksis pendidikan di Indonesia, meskipun dalan pengejewantahannya dewasa ini sering terinfiltrasi oleh determinasi filosofi Barat. Munculnya degradasi nilai dalam masyarakat sebagai akumulasi proses pendidikan yang lebih mengedepankan transformasi knowledge dari pada transformasi value dalam sistem pendidikan, telah menyentakan pemangku pendidikan di Indonesia untuk meletakkan kembali pilar filosofi kendidikan yang dicetuskan oleh tokoh-tokoh pendidikan di Indonesia. Pendidikan merupakan upaya mengembangkan potensi-potensi manusiawi peserta didik baik potensi fisik maupun potensi cipta, rasa, maupun karsanya agar potensi itu menjadi nyata dan dapat berfungsi dalam perjalanan hidupnya. Dasar pendidikan adalah cita-cita kemanusiaan universal maka dalam pemecahan masalah-masalah pendidikan yang komplek juga dibutuhkan filsafah-filsafah agar solusi pemecahan masalah tersebut juga dapat dirasakan manfaatnya bagi semua pihak. Salah satu tokoh yang memiliki filsafah pendidikan yaitu Ki Hadjar Dewantara, beliau adalah seorang bangsawan dari lingkungan Kraton Yogyakarta yang peduli dengan lingkungan pendidikan.
\end{abstract}

Kata Kunci: Filsafat Pendidikan; Ki Hajar Dewantara; Tokoh Timur

\begin{abstract}
The philosophical ideas of Ki Hajar Dewantara have become a fairly solid foundation in the praxis of education in Indonesia, although in its manifestation these days are often infiltrated by the determination of Western philosophy. The emergence of value degradation in the community as an accumulation of educational processes that prioritizes the transformation of knowledge rather than the transformation of values in the education system, has caused educational stakeholders in Indonesia to lay back the pillars of educational philosophy that were instigated by educational leaders in Indonesia. Education is an effort to develop the human potential of students both physical potential and the potential of creativity, taste, and work so that the potential becomes real and can function in the course of his life. The basis of education is the ideals of universal humanity, so in solving complex educational problems also philosophies are needed so that the solution to the problem can also be felt for all parties. One figure who has an educational philosophy is Ki Hajar Dewantara, he is a nobleman from the Yogyakarta Palace who cares about the educational environment.
\end{abstract}

Keywords: Philosophy of Education; Ki Hajar Dewantara; Eastern Figure

\section{Pendahuluan}

Filsafat pendidikan, secara harfiah mengandung substansi filsafat dan pendidikan. Filsafat (Philosophy) berasal dari kata Philos (cinta) dan Sophia (kebijaksanaan) bahasa Yunani yang menjadi asal muasal kata dari filosofi atau filsafat. Filosofi berarti cinta akan kebijaksanaan. Filosofi dikatakan sebagai ilmu yang menjadi dasar dari seluruh ilmu yang menjadi panutan manusia.Tanpa adanya sebuah filosofi maka ilmu yang lain tidak akan berkembang. Filosofi dapat berguna untuk mengentaskan manusia dari kehilangan jati diri yang memiliki sebuah tujuan 
dan arah. Secara steriotif, filsafat dapat dipandang sebagai berpikir reflektif-kritis terhadap suatu realita, dalam rangka mencari kebenaran/kebijaksanaan. Di sisi yang lain, pendidikan adalah upaya mengembangkan potensi-potensi manusiawi peserta didik baik potensi fisik potensi cipta, rasa, maupun karsanya, agar potensi itu menjadi nyata dan dapat berfungsi dalam perjalanan hidupnya. Dasar pendidikan adalah cita-cita kemanusiaan universal. Pendidikan bertujuan menyiapkan pribadi dalam keseimbangan, kesatuan, organis, harmonis, dan dinamis guna mencapai tujuan hidup kemanusiaan. Filsafat pendidikan adalah filsafat yang digunakan dalam studi mengenai masalah-masalah pendidikan.

Pandangan filsafat pendidikan sama dengan peranannya sebagai landasan filosofis yang menjiwai seluruh kebijaksanaan pelaksanaan pendidikan. Dimana landasan filosofis merupakan landasan yang berdasarkan atas filsafat. Landasan filsafat menalaah sesuatu secara radikal, menyeluruh, dan konseptual tentang religi dan etika yang bertumpu pada penalaran. Oleh karena itu antara filsafat dengan pendidikan sangat erat kaitannya, dimana filsafat mencoba merumuskan citra tentang manusia dan masyarakat, sedangkan pendidikan berusaha mewujudkan citra tersebut. Pendidikan adalah upaya mengembangkan potensi-potensi manusiawi peserta didik baik potensi fisik potensi cipta, rasa, maupun karsanya, agar potensi itu menjadi nyata dan dapat berfungsi dalam perjalanan hidupnya. Dasar pendidikan adalah cita-cita kemanusiaan universal. Pendidikan bertujuan menyiapkan pribadi dalam keseimbangan, kesatuan, organis, harmonis, dan dinamis guna mencapai tujuan hidup kemanusiaan.

Dalam menerapkan filsafat pendidikan, seorang guru sebagai pendidik, dia mengharapkan dan mempunyai hak bahwa ahli-ahli filsafat pendidikan menunjukkan dirinya pada masalah pendidikan pada umumnya serta bagaimana masalah itu mengganggu pada penyekolahan yang menyangkut masalah perumusan tujuan, kurikulum, organisasi sekolah dan sebagainya. Dan para pendidik juga mengharapkan dari ahli filsafat pendidikan suatu klasifikasi dari uraian lebih lanjut dari konsep, argumen dirinya, literatur pendidikan terutama dalam kotraversi pendidikan sistem-sistem, pengujian kopetensi minimal dan kesamaan kesepakatan pendidikan. Brubacher (1950) mengemukakan tentang hubungan antara filsafat dengan filsafat pendidikan, dalam hal ini pendidikan: bahwa filsafat tidak hanya melahirkan sains atau pengetahuan baru, melainkan juga melahirkan filsafat pendidikan. Filsafat merupakan kegiatan berpikir manusia yang berusaha untuk mencapai kebijakan dan kearifan, sedangkan filsafat pendidikan merupakan ilmu yang pada hakekatnya jawaban dari pertanyaan-pertanyaan yang timbul dalam lapangan pendidikan. Oleh karena bersifat filosofis, dengan sendirinya filsafat pendidikan ini hakekatnya adalah penerapan dari suatu analisa filosofis terhadap lapangan pendidikan.

Banyak aliran-aliran filsafat pendidikan yang mewarnai praktek pelaksanaan pendidikan, baik yang dicetuskan tokoh-tokoh dari dunia barat, maupun dari tokoh-tokoh dunia timur. Tokoh filsafat pendidikan yang muncul dari dunia timur yang cukup terkenal, khususnya di Indonesia adalah Ki Hajar Dewantara. Gagasan-gagasan filosofis Ki Hajar Dewantara telah menjadi pondasi yang cukup kokoh dalam praksis pendidikan di Indonesia, meskipun dalan pengejewantahannya dewasa ini sering terinfiltrasi oleh determinasi filosofi Barat. Munculnya degradasi nilai dalam masyarakat sebagai akumulasi proses pendidikan yang lebih mengedepankan transformasi knowledge dari pada transformasi value dalam sistem pendidikan, telah menyentakan pemangku pendidikan di Indonesia untuk meletakkan kembali pilar filosofi kendidikan yang dicetuskan oleh tokoh-tokoh pendidikan di Indonesia. Pendidikan merupakan upaya mengembangkan potensi-potensi manusiawi peserta didik baik potensi fisik maupun potensi cipta, rasa, maupun karsanya agar potensi itu menjadi nyata dan dapat berfungsi dalam perjalanan hidupnya. Dasar pendidikan adalah cita-cita kemanusiaan universal maka dalam pemecahan masalah-masalah pendidikan yang komplek juga dibutuhkan filsafah-filsafah agar solusi pemecahan masalah tersebut juga dapat dirasakan manfaatnya bagi semua pihak. Salah satu tokoh yang memiliki filsafah pendidikan yaitu Ki Hadjar Dewantara, beliau adalah seorang bangsawan dari lingkungan Kraton Yogyakarta yang peduli dengan lingkungan pendidikan.

Berangkat dari latar belakang di atas, maka dipandang perlu untuk mengkaji kembali secara kritis gagasan filosofi pendidikan Ki Hajar Dewantara dalam bentuk makalah untuk dijadikan bahan diskusi-reflektif dalam perkuliahan filsafat ilmu, terutama berkaitan dengan (1) latar belakang historis tercetusnya filosofi pendidikan Ki Hajar Dewantara, (2) substansi gagasan filosofi pendidikan Ki Hajar Dewantara, (3) implikasi teori-praktis gagasan filosofi pendidikan Ki Hajar Dewantara dalam praktek pendidikan. Berdasarkan latar belakang tersebut, dapat dirumuskan beberapa permasalahan yang menjadi fokus kajian dalam makalah ini, yakni (1) bagaimana latar belakang historis tercetusnya filsafat pendidikan Ki Hajar Dewantara?, (2) apa 
substansi gagasan filsafat pendidikan Ki Hajar Dewantara?, dan (3) bagaimana implikasi teoripraktis filsafat pendidikan Ki Hajar Dewantara?. Tujuan penulisan makalah ini adalah untuk mendeskripsikan latar belakang historid dan substansi gagasan-gagasan filosofis pendidikan $\mathrm{Ki}$ Hajar Dewantara dan implikasinya dalam teori-praktis kependidikan. Makalah ini diharapkan dapat bermanfaat untuk dijadikan pijakan kontemplasi berpikir/bertindak kritis dalam rangka mengampu perkembangan dinamika pendidikan di Indonesia dewasa ini.

\section{Metode}

Artikel ini disusun dengan menggunakan study kepustakaan. Sumber referensi primer dan sekunder digunakan agar mendapatkan pembahasan dan kemudian simpulan yang akurat.

\section{Hasil dan Pembahasan}

\section{Filsafat Pendidikan Ki Hajar Dewantara Latar Belakang Historis Filosopi Pendidikan Ki Hajar Dewantara}

Ki Hajar Dewantara Lahir di Yogyakarta pada tanggal 2 Mei 1889. Terlahir dengan nama Raden Mas Soewardi Soeryaningrat. la berasal dari lingkungan keluarga kraton Yogyakarta. Raden Mas Soewardi Soeryaningrat, saat genap berusia 40 tahun menurut hitungan Tahun Caka, berganti nama menjadi Ki Hadjar Dewantara. Semenjak saat itu, ia tidak lagi menggunakan gelar kebangsawanan di depan namanya. Hal ini dimaksudkan supaya ia dapat bebas dekat dengan rakyat, baik secara fisik maupun hatinya.

Ki Hadjar Dewantara masa kecilnya bernama R.M. Soewardi Surjaningrat, lahir pada hari Kamis Legi, tanggal 02 Puasa tahun Jawa, bertepatan dengan tanggal 2 Mei 1889 M. Ayahnya bernama G.P.H. Surjaningrat putra Kanjeng Hadipati Harjo Surjo Sasraningrat yang bergelar Sri Paku Alam ke-III. Ibunya adalah seorang putri keraton Yogyakarta yang lebih dikenal sebagai pewaris Kadilangu keturunan langsung Sunan Kalijogo (Darsiti Suratman, 1985: 2). Ki Hadjar Dewantara pertama kali masuk Europeesche Lagere School. Setelah tamat dari Europeesche Lagere School, Ki Hadjar melanjutkan pelajarannya ke STOVIA, singkatan dari School Tot Opleiding Van Indische Arsten. Ki Hadjar tidak menamatkan pelajaran di STOVIA. Ki Hajar juga mengikuti pendidikan sekolah guru yang disebut Lagere Onderwijs, hingga berhasil mendapatkan ijasah (Irna H.N., Hadi Soewito, 1985: 16).

Bersama dengan Tjipto Mangunkusumo pada permulaan Juli 1913 membentuk "Committee tot Herdenking van Nederlandsch Honderdjarige Vrijheid" (panitia peringatan 100 tahun kemerdekaan Nederland) yang dalam bahasa Indonesia disingkat "Komisi Bumi Putra". Panitia bermaksud akan mengeluarkan isi hati rakyat, memprotes adanya perayaan kemerdekaan Belanda karena rakyat Indonesia dipaksa secara halus harus memungut uang sampai ke pelosok-pelosok. Akibat terlalu banyak protes dalam artikel dan tulisan di brosur ketiga pemimpin Indische Party (tiga serangkai) ditangkap dan ditahan. Dalam waktu yang amat singkat, pada 18 Agustus 1913 keluarlah surat dari wali negara untuk ketiga pemimpin tersebut. Ketiganya dikenakan hukuman buang; Soewardi ke Bangka, Tjipto Mangunkusumo ke Banda Neira, dan Douwes Dekker ke Timur Kupang. Keputusan itu disertai ketetapan bahwa mereka bebas untuk berangkat keluar jajahan Belanda. Ketiganya ingin mengganti hukuman interniran dengan hukuman externir, dan memilih negeri Belanda sebagai tempat pengasingan mereka

Ketika di negeri Belanda perhatian Soewardi Soejaningrat tertarik pada masalahmasalah pendidikan dan pengajaran di samping bidang sosial politik. la menambah pengetahuannya dalam bidang pendidikan dan pada tahun 1915 memperoleh akte guru. Tokohtokoh besar dalam bidang pendidikan mulai dikenalnya, antara lain; J.J. Rousseau, Dr. Frobel, Dr. Montessori, Rabindranath Tagore, John Dewey, dan Kerschensteiner. Frobel ahli pendidikan terkenal dari Jerman pendiri "Kindergarten". Montessori sarjana wanita dari Italia pendiri "Casa dei Bambini". Rabindranath Tagore, pujangga terkenal dari India, pendiri perguruan "Santi Niketan". Pengalaman Ki Hadjar Dewantara dan kawan-kawannya di lapangan perjuangan politik, dengan melalui berbagai rintangan, penjara dan pembuangan dengan segala hasilnya, menimbulkan pikiran baru untuk meninjau cara-cara dan jalan untuk menuju kemerdekaan Indonesia (Muchammad Tauchid, 1963: 29). Ki Hadjar Dewantara yang terus berjuang tak kenal lelah tersebut dalam menghadapi berbagai masalah, ternyata dia menaruh perhatian terhadap pendidikan karakter bangsa. 
Ki Hajar Dewantara adalah Bapak Pendidikan Nasional. Hal itu karena beliau merupakan seorang tokoh yang tanpa jasa memerdekakan Indonesia. Pengabdian yang ia berikan begitu besar terhadap bangsanya. Banyaknya karya yang membuat Indonesia menjadi bangga pun sering ia lakukan. Bahkan saking begitu banyak membuat Indonesia bangga, tanggal lahir Ki Hajar Dewantara menjadi hari Pendidikan Nasional. Hari yang dikenal seluruh warga Indonesia. Hari seseorang yang dilahirkan untuk memerdekakan pendidikan di Indonesia. Dengan kepintaran, kebijaksanaan, tekun dan berani memerdekakan hak dari orang lain dan bangsanya melawan penjajah. Ki Hajar Dewantara berasal dari lingkungan keluarga Keraton Yogyakarta. Ki Hajar Dewantara lahir di Yogyakarta, 2 Mei 1889 meninggal di usia 69 tahun di Yogyakarta, 26 April 1959. Dengan nama kecil Raden Mas Soewardi Soerjaningrat (EYD: Suwardi Suryaningrat) setelah itu sejak 1922 menjadi Ki Hadjar Dewantara (EYD: Ki Hajar Dewantara, beberapa menuliskan bunyi bahasa Jawanya dengan Ki Hajar Dewantoro). Beliau merupakan aktivis pergerakan kemerdekaan Indonesia, kolumnis, politisi, dan pelopor pendidikan bagi kaum pribumi Indonesia saat zaman penjajahan Belanda. ELS merupakan sekolah dasar di Eropa, Belanda yang menjadi lulusan Ki Hajar Dewantara. Kemudian sempat melanjut ke STOVIA (Sekolah Dokter Bumiputera), tapi tidak sampai tamat karena sakit. Kemudian ia bekerja sebagai penulis dan wartawan di beberapa surat kabar, antara lain, Sediotomo, Midden Java, De Expres, Oetoesan Hindia, Kaoem Moeda, Tjahaja Timoer, dan Poesara. Pada masanya, ia tergolong penulis handal. Tulisan-tulisannya komunikatif dan tajam dengan semangat antikolonial. Banyak karya-karya yang dimiliki beliau. Berbagai macam cara yang dilakukan Ki Hajar dewantara demi memperjuangkan kemerdekaan pendidikan Indonesia. Salah satunya dengan seringnya mengubah namanya sediri. Hal tersebut dimasudkan untuk menunjukkan perubahan sikapnya dalam melaksanakan pendidikan yaitu dari satria pinandita ke pinandita satria yaitu dari pahlawan yang berwatak guru spiritual ke guru spiritual yang berjiwa ksatria, yang mempersiapkan diri dan peserta didik untuk melindungi bangsa dan negara.

Tak berhasil menyelesaikan pendidikannya di STOVIA, tak membuat Ki Hajar Dewantara vakum, beliaupun mulai menulis untuk beberapa surat kabar sebagai wartawan muda. Selain itu beliau juga aktif di berbagai kegiatan sosial dan politik. Sebagai seorang wartawan tulisan-tulisan beliau dikenal sangat patriotik dan mampu membangkitkan semangat antikolonial bagi pembacanya. Tulisan Ki Hajar Dewantara yang terkenal anatarlain "Seandainya Aku Seorang Belanda" (judul asli: Als ik eens Nederlander was), dimuat dalam surat kabar de Expres milik Dr. Douwes Dekker, tahun 1913. Artikel ini ditulis sebagai protes atas rencana pemerintah Belanda untuk mengumpulkan sumbangan dari Hindia Belanda (Indonesia), yang saat itu masih belum merdeka, untuk perayaan kemerdekaan Belanda dari Perancis.

Sindiran Ki Hajar Dewantara melalui tulisan-tulisannya di beberapa surat kabar menyulut kemarahan Belanda, puncaknya Gubernur Jendral Idenburg memerintahkan agar Ki Hajar Dewantara di asingkan ke Pulau Bangka tanpa proses peradilan terlebih dahulu. Atas permintaan kedua rekannya yang juga mengalami hukuman pengasingan yaitu dr. Douwes Dekker dan dr. Cipto Mangoenkoesoemo, pengasingan mereka dialihkan ke negeri Belanda. Masa pembuangan di negeri Belanda tersebut tidak disia-siakan oleh Ki Hajar Dewantara untuk mendalami bidang pendidikan dan pengajaran, hingga akhirnya memperoleh sertifikat Europeesche Akte.

Sekembalinya ke tanah air pada tahun 1918, Ki Hajar Dewantara mencurahkan perhatiannya di bidang pendidikan sebagai salah satu bentuk perjuangan meraih kemerdekaan. Bersama rekanrekan seperjuangannya lainnya, Ki Hajar mendirikan Nationaal Onderwijs Institut Tamansiswa atau lebih dikenal dengan Perguruan Nasional Taman Siswa pada 3 Juli 1922. Taman Siswa merupakan sebuah perguruan yang bercorak nasional yang menekankan rasa kebangsaan dan cinta tanah air serta semangat berjuang untuk memperoleh kemerdekaan. Perjuangan Ki Hajar Dewantara tak hanya melalui Taman siswa, sebagai penulis, Ki Hajar Dewantara tetap produktif menulis untuk berbagai surat kabar. Hanya saja kali ini tulisannya tidak bernuansa politik, namun beralih ke bidang pendidikan dan kebudayaan. Tulisan KI Hajar Dewantara berisi konsep-konsep pendidikan dan kebudayaan yang berwawasan kebangsaan. Melalui konsep-konsep itulah dia berhasil meletakkan dasar-dasar pendidikan nasional bagi bangsa Indonesia.

Dalam perjuangannya terhadap pendidikan bangsanya, Ki Hajar Dewantara mempunyai Semboyan yaitu tut wuri handayani (dari belakang seorang guru harus bisa memberikan dorongan dan arahan), ing madya mangun karsa (di tengah atau di antara murid, guru harus menciptakan prakarsa dan ide), dan ing ngarsa sung tulada (di depan, seorang pendidik harus memberi teladan atau contoh tindakan baik). Semboyan ini masih tetap dipakai dalam dunia pendidikan kita, terutama di sekolah-sekolah Taman Siswa. Di Usianya yang genap 40 tahun, Ki Hajar Dewantara mencabut gelar kebangsawanannya dan mengganti nama aslinya Raden Mas 
Soewardi Soerjaningrat menjadi Ki Hadjar Dewantara. Hal ini dimaksudkan agar beliau dapat bebas dekat dengan rakyat, baik secara fisik maupun hati. Pada masa pendudukan Jepang, Ki Hajar Dewantara diangkat sebagai salah satu pimpinan pada organisasi Putera bersama-sama dengan Ir. Soekarno, Drs. Muhammad Hatta dan K.H. Mas Mansur. Dimasa kemerdekaan Ki Hajar Dewantara dingkat sebagai Menteri Pendidikan, Pengajaran dan Kebudayaan yang pertama. Perjuangan Ki Hajar Dewantara terhadap pendidikan Indonesia membuat beliau layak di anugerahi gelar pahlawan pendidikan Indonesia. Tak berlebihan pula jika tanggal lahir beliau, 2 Mei diperingati sebagai hari Pendidikan Nasional untuk mengenang dan sebagai penyemangat bagi kita untuk meneruskan prakarsa dan pemikiran-pemikiran beliau terhadap pendidikan Indonesia.

\section{Substansi Gagasan Filosofi Pendidikan Ki Hajar Dewantara}

Terbelenggu dalam pusaran tirani penjajahan Belanda, telah mendorong Ki Hajar Dewantara untuk memaknai pendidikan secara filosofi sebagai upaya memerdekakan manusia dalam aspek lahiriah (kemiskinan dan kebodohan), dan batiniah (otonomi berpikir dan mengambil keputusan, martabat, mentalitas demokratik). Filosofi dalam pendidikan mencakup suatu kebijakan-kebijakan pendidikan yang baru, mengusulkan cita-cita yang baru tanpa mempertimbangkan persoalan filosofis seperti hakikat kehidupan yang baik, kemana pendidikan diarahkan. Sebuah filosofi memiliki bagian yang penting yaitu mencari sebuah norma-norma serta tujuan. Dengan itu filosofi dapat mendorong manusia memperluas bidang kesadaran untuk menjadi lebih baik, lebih cerdas dan lebih aktif. Selain itu dapat menumbuhkan keyakinan akan agama dengan fondasi yang matang secara intelektual dalam diri manusia. Bagi Ki Hajar Dewantara, para guru hendaknya menjadi pribadi yang bermutu dalam kepribadian dan kerohanian, baru kemudian menyediakan diri untuk menjadi pahlawan dan juga menyiapkan para peserta didik untuk menjadi pembela nusa dan bangsa. Dengan kata lain, yang diutamakan sebagai pendidik pertama-tama adalah fungsinya sebagai model atau figure keteladanan, baru kemudian sebagai fasilitator atau pengajar. Oleh karena itu, nama Hajar Dewantara sendiri memiliki makna sebagai guru yang mengajarkan kebaikan, keluhuran, keutamaan. Menurut Ki Hajar Dewantara, pendidikan adalah tuntunan di dalam hidup tumbuhnya anak-anak. Adapun tujuannya adalah menuntun segala kekuatan kodrat yang ada pada anak-anak itu agar mereka sebagai manusia dan anggota masyarakat dapatlah mencapai keselamatan dan kebahagiaan setinggi-tingginya. Dengan berbagai ide yang dimiliki dari Ki Hajar Dewantara ada satu konsep yang terlupakan. Ki Hajar pernah melontarkan konsep belajar 3 dinding. Kalau kita mengingat masa lalu ketika masih di bangku sekolah, bentuk ruang kelas kita rata-rata adalah persegi empat. Nah, Ki Hajar menyarankan ruang kelas itu hanya dibangun 3 sisi dinding saja. Ada satu sisi yang terbuka. Konsep ini bukan main-main filosofinya. Dengan ada satu dinding yang terbuka, maka seolah hendak menegaskan tidak ada batas atau jarak antara di dalam kelas dengan realita di luar.

Coba bandingkan dengan bentuk kelas kita dulu saat kecil. Empat dinding tembok, dengan jendela tinggi-tinggi, sehingga kita yang masih kecil tidak bisa melihat keluar. Lalu biasanya di dinding digantungi foto-foto pahlawan perang yang angker-angker, dari $\mathrm{Pa} \square$ imura, Teuku Umar, Diponegoro sampai Sultan Hasanudin. Jarang sekali ada yang memasang foto pujangga masa lalu seperti Buya Hamka, Ranggawarsito, Marah Rusli, dll. Paling-paling pujangga yang sempat diingat anak-anak SD adalah WR Supratman. Konsep menyatunya kelas tempat belajar dengan realitas yang ditawarkan Ki Hajar, mungkin memang bukan orisinil dari Beliau. Mungkin konsep ini sudah ada sebelumnya Ki Hajar hidup. Namun ketika Ki Hajar merumuskan konsep ini dengan istilah 3 dinding, menunjukkan betapa luasnya wawasan Beliau dan mampu mengadaptasi konsep tersebut dalam budaya Indonesia.

Banyak karya beliau yang menjadi landasan rakyat Indonesia dalam mengembangkan pendidikan, khususnya kalimat filosofis (selain dari konsep 3 dinding diatas) seperti ING NGARSO SUNTOLODO, ING MADYO MANGUN KARSO, TUT WURI HANDAYANI (Di depan memberi teladan, di tengah memberi bimbingan, di belakang memberi dorongan).

Menurut Ki Hajar Dewantara, Pendidikan yaitu tuntutan di dalam hidup tumbuhnya anakanak, adapun maksudnya, pendidikan yaitu menuntun segala kekuatan kodrat yang ada pada anak-anak itu, agar mereka sebagai manusia dan sebagai anggota masyarakat dapatlah mencapai keselamatan dan kebahagiaan setinggi-tingginya. Lingkungan pendidikan meliputi lingkungan keluarga, lingkungan sekolah, dan lingkungan organisasi pemuda, yang ia sebut dengan Tri Pusat Pendidikan. a. Lingkungan Keluarga (Primary Community); Pendidikan Keluarga berfungsi: (1). Sebagai pengalaman pertama masa kanak-kanak, (2). Menjamin 
kehidupan emosional anak, (3). Menanamkan dasar pendidikan moral, (4). Memberikan dasar pendidikan sosial, dan (5). Meletakkan dasar-dasar pendidikan agama bagi anak-anak. b. Lingkungan Sekolah; Tidak semua tugas mendidik dapat dilaksanakan oleh orang tua dalam keluarga, terutama dalam hal ilmu pengetahuan dan berbagai macam ketrampilan. Karena jika ditilik dari sejarah perkembangan profesi guru, tugas mengajar sebenarnya adalah pelimpahan dari tugas orang tua karena tidak mampu lagi memberikan pengetahuan, ketrampilan, dan sikapsikap tertentu sesuai dengan perkembangan zaman. Fungsi Sekolah antara lain: (1) Sekolah membantu orang tua mengerjakan kebiasaan-kebiasaan yang baik serta menanamkan budi pekerti yang baik, (2) Sekolah memberikan pendidikan untuk kehidupan di dalam masyarakat yang sukar atau tidak dapat diberikan di rumah, (3) Sekolah melatih anak-anak memperoleh kecakapan-kecakapan seperti membaca, menulis, berhitung, menggambar serta ilmu-ilmu lain yang sifatnya mengembangkan kecerdasan dan pengetahuan, (4). Di sekolah diberikan pelajaran etika, keagamaan, estetika, membedakan moral, (5). Memelihara warisan budaya yang hidup dalam masyarakat dengan jalan menyampaikan warisan kebudayaan kepada generasi muda, dalam hal ini tentunya anak didik. c. Lingkungan Organisasi Pemuda. Peran organisasi pemuda yang terutama adalah mengupayakan pengembangan sosialisasi kehidupan pemuda. Melalui organisasi pemuda berkembanglah semacam kesadaran sosial, kecakapan-kecakapan di dalam pergaulan dengan sesama kawan (social skill) dan sikap yang tepat di dalam membina hubungan dengan sesama manusia (social attitude).

Ki Hajar Dewantara senantiasa melihat manusia lebih pada sisi kehidupan psikologiknya, karena manusia memiliki daya jiwa yaitu cipta, karsa dan karya. Pengembangan manusia seutuhnya menuntut pengembangan semua daya secara seimbang. Pengembangan yang terlalu menitikberatkan pada satu daya saja akan menghasilkan ketidakutuhan perkembangan sebagai manusia. Beliau mengatakan bahwa pendidikan yang menekankan pada aspek intelektual belaka hanya akan menjauhkan peserta didik dari masyarakatnya. Dan ternyata pendidikan sampai sekarang ini hanya menekankan pada pengembangan daya cipta, dan kurang memperhatikan pengembangan olah rasa dan karsa. Jika berlanjut terus akan menjadikan manusia kurang humanis atau manusiawi. Dari titik pandang sosio-anthropologis, kekhasan manusia yang membedakannya dengan makhluk lain adalah bahwa manusia itu berbudaya, sedangkan makhluk lainnya tidak berbudaya. Maka salah satu cara yang efektif untuk menjadikan manusia lebih manusiawi adalah dengan mengembangkan kebudayaannya. Persoalannya budaya dalam masyarakat itu berbeda-beda. Ki Hajar Dewantara sendiri dengan mengubah namanya ingin menunjukkan perubahan sikapnya dalam melaksanakan pendidikan yaitu dari satria pinandita ke pinandita satria yaitu dari pahlawan yang berwatak guru spiritual ke guru spiritual yang berjiwa ksatria, yang mempersiapkan diri dan peserta didik untuk melindungi bangsa dan negara. Bagi Ki Hajar Dewantara, para guru hendaknya menjadi pribadi yang bermutu dalam kepribadian dan kerohanian, baru kemudian menyediakan diri untuk menjadi pahlawan dan juga menyiapkan para peserta didik untuk menjadi pembela nusa dan bangsa. Dengan kata lain, yang diutamakan sebagai pendidik pertama-tama adalah fungsinya sebagai model atau figure keteladanan, baru kemudian sebagai fasilitator atau pengajar. Oleh karena itu, nama Hajar Dewantara sendiri memiliki makna sebagai guru yang mengajarkan kebaikan, keluhuran, keutamaan. Pendidik atau Sang Hajar adalah seseorang yang memiliki kelebihan di bidang keagamaan dan keimanan, sekaligus masalah-masalah kemasyarakatan. Modelnya adalah Kyai Semar yang sukses menjadi perantara antara Tuhan dan manusia, mewujudkan kehendak Tuhan di dunia ini. Sebagai pendidik yang merupakan perantara Tuhan maka guru sejati sebenarnya adalah berwatak pandita juga, yaitu mampu menyampaikan kehendak Tuhan dan membawa keselamatan. Manusia merdeka adalah tujuan dari pendidikan nasional kita. Merdeka baik secara fisik, mental dan kerohanian. Suasana yang dibutuhkan dalam dunia pendidikan adalah suasana yang berprinsip pada kekeluargaan, kebaikan hati, empati, cintakasih dan penghargaan terhadap masing-masing anggotanya. Maka hak setiap individu hendaknya dihormati; pendidikan hendaknya membantu peserta didik untuk menjadi merdeka dan independen secara fisik, mental dan spiritual. Pendidikan juga hendaknya tidak hanya sekedar mengembangkan aspek intelektual sebab akan memisahkan dari orang kebanyakan. Pendidikan hendaknya memperkaya setiap individu tetapi perbedaan antara masing-masing pribadi harus tetap dipertimbangkan. Pendidikan hendaknya memperkuat rasa percaya diri, mengembangkan hara diri. Setiap orang harus hidup sederhana dan guru hendaknya rela mengorbankan kepentingan-kepentingan pribadinya demi kebahagiaan para peserta didiknya. Metode yang yang sesuai dengan sistem pendidikan ini menurut Ki Hajar adalah sistem among yaitu metode pengajaran dan pendidikan yang berdasarkan pada asih, asah dan asuh (care and dedication based on love). Guru yang efektif 
memiliki keunggulan dalam mengajar (fasilitator); dalam hubungan (relasi dan komunikasi) dengan peserta didik dan anggota komunitas sekolah; dan juga relasi dan komunikasinya dengan pihak lain (orang tua, komite sekolah, pihak terkait); segi administrasi sebagai guru; dan sikap profesionalitasnya. Sikap-sikap profesional itu meliputi antara lain: keinginan untuk memperbaiki diri dan keinginan untuk mengikuti perkembangan zaman. Maka penting pula membangun suatu etos kerja yang positif yaitu: menjunjung tinggi pekerjaan; menjaga harga diri dalam melaksanakan pekerjaan, dan keinginan untuk melayani masyarakat. Dalam kaitan dengan ini penting juga performance/penampilan seorang profesional: secara fisik, intelektual, relasi sosial, kepribadian, nilai-nilai dan kerohanian serta mampu menjadi motivator. Singkatnya perlu adanya peningkatan mutu kinerja yang profesional, produktif dan kolaboratif demi pemanusiaan secara utuh setiap peserta didik.

Ketika Soewardi kembali dari pengasingan Negara Belanda ke Indonesia pada bulan September 1919. Segera kemudian ia bergabung dalam sekolah binaan saudaranya. Pengalaman mengajar ini kemudian digunakannya untuk mengembangkan konsep mengajar bagi sekolah yang ia dirikan pada tanggal 3 Juli 1922: Nationaal Onderwijs Instituut Tamansiswa atau Perguruan Nasional Tamansiswa. Semboyan dalam sistem pendidikan yang dipakainya kini sangat dikenal di kalangan pendidikan Indonesia. Secara utuh, semboyan itu dalam bahasa Jawa berbunyi ing ngarso sung tulodo, ing madyo mangun karso, tut wuri handayani. ("di depan memberi contoh, di tengah memberi semangat, di belakang memberi dorongan"). Semboyan ini masih tetap dipakai dalam dunia pendidikan rakyat Indonesia, terlebih di sekolah-sekolah Perguruan Tamansiswa. Semboyan itu menggambarkan peran seorang guru atau pendidik dalam dunia pendidikan. Kumpulan peran yang cukup lengkap, yaitu: menjadi teladan, memberikan semangat, dan memberikan dorongan. Luar biasa sebenarnya seorang guru itu, bila dimaknai dan dilaksanakan dengan sungguh-sungguh akan berpengaruh sangat bagus kepada anak didiknya. Dari ketiga semboyan tersebut yang paling banyak kita kenal sekarang adalah Tut Wuri Handayani, biasanya tertulis di topi siswa SD sampai dengan SLTA. Tapi sampai sekarang saya tidak tau (entah lupa atau tidak pernah tahu) kenapa yang lebih populer semboyan Tut Wuri Handayani (dari belakang mendorong) bukan Ing Ngarso Sungtulodo (dari depan memberikan teladan) ataupun Ing Madya Mangunkarso (dari tengah memberikan semangat).

Menurut Ki Hajar Dewantara, dalam pendidikan perlu ditanamkan sejak dini bahwa keberadaan seorang pribadi, jauh lebih penting dan tentu tidak persis sama dengan apa yang menjadi miliknya dan apa yang telah dilakukannya. Sebab manusia tidak sekedar pemilik kekayaan dan juga menjalankan suatu fungsi tertentu. Pendidikan yang humanis menekankan pentingnya pelestarian eksistensi manusia, dalam arti membantu manusia lebih manusiawi, lebih berbudaya, sebagai manusia yang utuh berkembang. Inilah yang menurut Ki Hajar Dewantara harus dikembangkan karena pendidikan juga menyangkut daya cipta (kognitif), daya rasa (afektif), dan daya karsa (konatif)). Singkatnya, "educate the head, the heart, and the hand !"

Pendidikan adalah suatu proses yang bertujuan untuk mengembangkan potensi-potensi individu (peserta didik) baik potensi fisik maupun potensi cipta, rasa, maupun karsanya agar potensi itu menjadi nyata dan dapat berfungsi dalam perjalanan hidupnya. Filsafat erat kaitannya dengan pendidikan, karena filsafat merupakan akar dari segala macam ilmu termasuk ilmu pendidikan. Peranan filsafat sangat terlihat dari digunakannya filsafat sebagai cara pandang dalam memecahkan permasalahan yang tidak bisa diatasi dengan teoritik. Salah satu tokoh yang dapat direpresentatifkan dengan pendidikan di Indonesia adalah Ki Hajar Dewantara.Tidak dipungkiri bahwa beliau memiliki andil yang besar dalam perkembangan pendidikan di Indonesia. Hal ini dipastikan dengan diraihnya gelar sebagai Bapak Pendidikan Nasional, dan tanggal lahirnya yakni, 2 Mei diperingati sebagai hari Pendidikan Nasional. Sebelum menelisik jauh filsafat Ki Hajar Dewantara tentang pendidikan di Indonesia kita telisik dulu makna filsafat dari nama Ki Hajar. Nama Hajar Dewantara sendiri memiliki makna sebagai guru yang mengajarkan kebaikan, keluhuran, keutamaan. Pendidik atau Sang Hajar adalah seseorang yang memiliki kelebihan di bidang keagamaan dan keimanan, sekaligus masalah-masalah sosial kemasyarakatan. Sebagai pendidik yang merupakan perantara Tuhan maka guru sejati seharusnya berwatak pandita, yaitu mampu menyampaikan kehendak Tuhan dan membawa keselamatan. Semboyan pendidikan yang diusung oleh Ki Hajar Dewantara adalah "Ing ngarso sung tulodho, ing madyo mangun karso, tut wuri handayani", yang dapat diartikan sebagai: Ing ngarso sung tulodho : seorang pemimpin apabila di depan harus bisa memberikan contoh atau menjadi panutan bagi yang dipimpin (warga atau peserta didik).Ing madyo mangun karso : seorang pemimpin apabila berada di tengah-tengah masyarakat harus bisa membangkitkan semangat atau memberi motivasi supaya lebih maju, atau lebih baik. Tut wuri handayani : seorang 
pemimpin apabila berada di belakang harus bisa mendorong yang dipimpin supaya senantiasa lebih maju. Dasar yang paling penting dalam pendidikan menurut Ki Hajar Dewantara adalah adanya persamaan persepsi antara penegak atau pemimpin pendidikan tentang arti "mendidik" itu sendiri. Beliau menyatakan bahwa mendidik itu bersifat humanisasi, yakni mendidik adalah proses memanusiakan manusia dengan adanya pendidikan diharapkan derajat hidup manusia bisa bergerak vertikal ke atas ke taraf insani yang lebih baik dari sebelumnya.

Dalam konsep pendidikan Ki Hajar Dewantara ada dua hal yang harus dibedakan yaitu, "Pengajaran" dan "Pendidikan" yang harus bersinergis satu sama lain. Adapun menurut beliau pengajaran bersifat memerdekakan manusia dari aspek hidup lahiriah (kemiskinan dan kebodohan). Sedangkan pendidikan mengarah pada memerdekakan manusia dari aspek hidup batin (otonomi berpikir dan mengambil keputusan, martabat, mentalitas demokratik). Jadi jelaslah bahwa manusia yang merdeka adalah manusia yang hidupnya secara lahir dan batin tidak terganggu kepada orang lain, akan tetapi ia mampu bersandar dan berdiri di atas kakinya sendiri. Artinya sistem pendidikan itu mampu menjadikan setiap individu hidup mandiri dan berpikir sendiri. Sistem pendidikan yang sebenarnya adalah bersifat mengasuh, melindungi, dan meneladani. Maka untuk dapat mencapai ini perlulah ketetapan pikiran dan batin yang akan menentukan kualitas seseorang sehingga rasa mantap tadi dapat tercapai. "Sifat umum pendidikan yang beliau canangkan adalah segala daya-upaya untuk memajukan bertumbuhnya budi pekerti (kekuatan batin, karakter), pikiran, (intelect), dan tubuh anak: dalam pengertian taman siswa tidak boleh dipisah-pisahkan bagianbagian itu, agar supaya kita memajukan kesempurnaan hidup, yakni kehidupan dan penghidupan anakanak yang kita didik selaras dengan dunia-nya." Dari pernyataan ini dapat disimpulkan bahwa makna kata pendidikan jauh lebih luas daripada pengajaran. Pendidikan mencakup manusia seutuhnya, baik itu pendidikan intelektual, moralitas (nilai-nilai), dan budi pekerti. Pendidikan menurut paham ini adalah pendidikan yang beralaskan garis-hidup dari bangsanya dan ditujukan untuk keperluan prikehidupan yang dapat mengangkat derajat negara dan rakyatnya, agar dapat bekerja bersama-sama dengan bangsa lain demi kemuliaan segenap manusia di seluruh dunia. Konsepkonsep pendidikan Ki Hajar Dewantara dapat diterjemahkan bahwasanya pendidikan di Indonesia haruslah memiliki tiga landasan filosofis, yaitu: nasionalistik maksudnya adalah budaya nasional, bangsa yang merdeka dan independen baik secara politis, ekonomis, universalictik dan spiritualistik. Universal artinya berdasarkan pada hukum alam, segala sesuatu merupakan perwujudan dari kehendak Tuhan. Prinsip dasarnya adalah kemerdekaan, pendidikan hendaknya membantu peserta didik untuk menjadi merdeka dan independen secara fisik dan mental. Spiritual, yaitu pendidikan hendaknya tidak hanya mengembangkan aspek intelektual saja namun pendidikan hendaknya juga memperkuat rasa percaya diri, dann mengembangkan harga diri.

Dalam pemikiran Ki Hajar Dewantara metode yang sesuai dengan sistem pendidikan ini adalah sistem among, yaitu metode pengajaran dan pendidikan yang berdasarkan pada asih, asah, dan asuh. Metode ini secara teknik pengajaran meliputi kepala, hati, dan panca indera. Sehingga output pendidikan yang dihasilkan adalah peserta didik yang berkepribadian merdeka, sehat fisik, sehat mental, cerdas, menjadi anggota masyarakat yang berguna, dan bertanggungjawab atas kebahagiaan dirinya dan kesejahteraan orang lain.Orientasi asas dan dasar pendidikan dari Ki Hajar Dewantara diupayakan sebagai asas perjuangan yang diperlukan pada waktu itu. Pengaruh pemikiran pertama dalam pendidikan adalah dasar kemerdekaan bagi tiap-tiap orang untuk mengatur dirinya sendiri. Bila diterapkan kepada pelaksanaan pengajaran maka hal itu merupakan upaya di dalam mendidik peserta didik supaya dapat berperasaan, berpikiran dan bekerja merdeka dmi pencapaian tujuannya dan perlunya kemajuan sejati untuk diperoleh dalam perkembangan kodrati. Hak mengatur diri sendiri berdiri bersama dengan tertib, damai dan bertumbuh menurut kodrat. Ketiga hal ini merupakan dasar alat pendidikan bagi anakanak yang disebut "among metode", yang salah atu seginya ialah mewajibkan guru-guru sebagai pemimpin yang berdiri di belakang tetapi mempengaruhi dengan memberi kesempatan anak didik untuk berjalan sendiri. Maka dengan demikian pendidikan di Indonesia akan tetap dan selalu berproses berdasarkan semboyan "Ing ngarso sung tulodho, ing madyo mangun karso, tut wuri handayani"

Pada jaman kemajuan teknologi sekarang ini, sebagian besar manusia dipengaruhi perilakunya oleh pesatnya perkembangan dan kecanggihan teknologi (teknologi informasi). Banyak orang terbuai dengan teknologi yang canggih, sehingga melupakan aspek-aspek lain dalam kehidupannya, seperti pentingnya membangun relasi dengan orang lain, perlunya melakukan aktivitas sosial di dalam masyarakat, pentingnya menghargai sesama lebih daripada apa yang berhasil dibuatnya, dan lain-lain. 
Seringkali teknologi yang dibuat manusia untuk membantu manusia tidak lagi dikuasai oleh manusia tetapi sebaliknya manusia yang terkuasai oleh kemajuan teknologi. Manusia tidak lagi bebas menumbuhkembangkan dirinya menjadi manusia seutuhnya dengan segala aspeknya. Keberadaan manusia pada zaman ini seringkali diukur dari "to have" (apa saja materi yang dimilikinya) dan "to do" (apa saja yang telah berhasil/tidak berhasil dilakukannya) daripada keberadaan pribadi yang bersangkutan ("to be" atau "being"nya). Dalam pendidikan perlu ditanamkan sejak dini bahwa keberadaan seorang pribadi, jauh lebih penting dan tentu tidak persis sama dengan apa yang menjadi miliknya dan apa yang telah dilakukannya. Sebab manusia tidak sekedar pemilik kekayaan dan juga menjalankan suatu fungsi tertentu. Pendidikan yang humanis menekankan pentingnya pelestarian eksistensi manusia, dalam arti membantu manusia lebih manusiawi, lebih berbudaya, sebagai manusia yang utuh berkembang (menurut Ki Hajar Dewantara menyangkut daya cipta (kognitif), daya rasa (afektif), dan daya karsa (konatif)). Singkatnya, "educate the head, the heart, and the hand!".

Di tengah-tengah maraknya globalisasi komunikasi dan teknologi, manusia makin bersikap individualis. Mereka "gandrung teknologi", asyik dan terpesona dengan penemuanpenemuan/barang-barang baru dalam bidang iptek yang serba canggih, sehingga cenderung melupakan kesejahteraan dirinya sendiri sebagai pribadi manusia dan semakin melupakan aspek sosialitas dirinya. Oleh karena itu, pendidikan dan pembelajaran hendaknya diperbaiki sehingga memberi keseimbangan pada aspek individualitas ke aspek sosialitas atau kehidupan kebersamaan sebagai masyarakat manusia. Pendidikan dan pembelajaran hendaknya juga dikembalikan kepada aspek-aspek kemanusiaan yang perlu ditumbuhkembangkan pada diri peserta didik.

Ki Hajar Dewantara, pendidik asli Indonesia, melihat manusia lebih pada sisi kehidupan psikologiknya. Menurutnya manusia memiliki daya jiwa yaitu cipta, karsa dan karya. Pengembangan manusia seutuhnya menuntut pengembangan semua daya secara seimbang. Pengembangan yang terlalu menitikberatkan pada satu daya saja akan menghasilkan ketidakutuhan perkembangan sebagai manusia. Beliau mengatakan bahwa pendidikan yang menekankan pada aspek intelektual belaka hanya akan menjauhkan peserta didik dari masyarakatnya. Dan ternyata pendidikan sampai sekarang ini hanya menekankan pada pengembangan daya cipta, dan kurang memperhatikan pengembangan olah rasa dan karsa. Jika berlanjut terus akan menjadikan manusia kurang humanis atau manusiawi.

Dari titik pandang sosio-anthropologis, kekhasan manusia yang membedakannya dengan makhluk lain adalah bahwa manusia itu berbudaya, sedangkan makhluk lainnya tidak berbudaya. Maka salah satu cara yang efektif untuk menjadikan manusia lebih manusiawi adalah dengan mengembangkan kebudayaannya. Persoalannya budaya dalam masyarakat itu berbeda-beda. Dalam masalah kebudayaan berlaku pepatah:"Lain ladang lain belalang, lain lubuk lain ikannya." Manusia akan benar-benar menjadi manusia kalau ia hidup dalam budayanya sendiri. Manusia yang seutuhnya antara lain dimengerti sebagai manusia itu sendiri ditambah dengan budaya masyarakat yang melingkupinya.

Ki Hajar Dewantara sendiri dengan mengubah namanya ingin menunjukkan perubahan sikapnya dalam melaksanakan pendidikan yaitu dari satria pinandita ke pinandita satria yaitu dari pahlawan yang berwatak guru spiritual ke guru spiritual yang berjiwa ksatria, yang mempersiapkan diri dan peserta didik untuk melindungi bangsa dan negara. Bagi Ki Hajar Dewantara, para guru hendaknya menjadi pribadi yang bermutu dalam kepribadian dan kerohanian, baru kemudian menyediakan diri untuk menjadi pahlawan dan juga menyiapkan para peserta didik untuk menjadi pembela nusa dan bangsa. Dengan kata lain, yang diutamakan sebagai pendidik pertama-tama adalah fungsinya sebagai model atau figure keteladanan, baru kemudian sebagai fasilitator atau pengajar. Oleh karena itu, nama Hajar Dewantara sendiri memiliki makna sebagai guru yang mengajarkan kebaikan, keluhuran, keutamaan. Pendidik atau Sang Hajar adalah seseorang yang memiliki kelebihan di bidang keagamaan dan keimanan, sekaligus masalah-masalah sosial kemasyarakatan. Modelnya adalah Kyai Semar (menjadi perantara antara Tuhan dan manusia, mewujudkan kehendak Tuhan di dunia ini). Sebagai pendidik yang merupakan perantara Tuhan maka guru sejati sebenarnya adalah berwatak pandita juga, yaitu mampu menyampaikan kehendak Tuhan dan membawa keselamatan.

Manusia merdeka adalah tujuan pendidikan Taman Siswa. Merdeka baik secara fisik, mental dan kerohanian. Namun kemerdekaan pribadi ini dibatasi oleh tertib damainya kehidupan bersama dan ini mendukung sikap-sikap seperti keselarasan, kekeluargaan, musyawarah, toleransi, kebersamaan, demokrasi, tanggungjawab dan disiplin. Sedangkan maksud pendirian Taman Siswa adalah membangun budayanya sendiri, jalan hidup sendiri dengan 
mengembangkan rasa merdeka dalam hati setiap orang melalui media pendidikan yang berlandaskan pada aspek-aspek nasional. Landasan filosofisnya adalah nasionalistik dan universalistik. Nasionalistik maksudnya adalah budaya nasional, bangsa yang merdeka dan independen baik secara politis, ekonomis, maupun spiritual. Universal artinya berdasarkan pada hukum alam (natural law), segala sesuatu merupakan perwujudan dari kehendak Tuhan. Prinsip dasarnya adalah kemerdekaan, merdeka dari segala hambatan cinta, kebahagiaan, keadilan, dan kedamaian tumbuh dalam diri (hati) manusia. Suasana yang dibutuhkan dalam dunia pendidikan adalah suasana yang berprinsip pada kekeluargaan, kebaikan hati, empati, cintakasih dan penghargaan terhadap masing-masing anggotanya. Maka hak setiap individu hendaknya dihormati; pendidikan hendaknya membantu peserta didik untuk menjadi merdeka dan independen secara fisik, mental dan spiritual; pendidikan hendaknya tidak hanya mengembangkan aspek intelektual sebab akan memisahkan dari orang kebanyakan; pendidikan hendaknya memperkaya setiap individu tetapi perbedaan antara masing-masing pribadi harus tetap dipertimbangkan; pendidikan hendaknya memperkuat rasa percaya diri, mengembangkan hara diri; setiap orang harus hidup sederhana dan guru hendaknya rela mengorbankan kepentingan-kepentingan pribadinya demi kebahagiaan para peserta didiknya. Peserta didik yang dihasilkan adalah peserta didik yang berkepribadian merdeka, sehat fisik, sehat mental, cerdas, menjadi anggota masyarakat yang berguna, dan bertanggungjawab atas kebahagiaan dirinya dan kesejahteraan orang lain. Metode yang yang sesuai dengan sistem pendidikan ini adalah sistem among yaitu metode pengajaran dan pendidikan yang berdasarkan pada asih, asah dan asuh (care and dedication based on love). Yang dimaksud dengan manusia merdeka adalah seseorang yang mampu berkembang secara utuh dan selaras dari segala aspek kemanusiaannya dan yang mampu menghargai dan menghormati kemanusiaan setiap orang. Oleh karena itu bagi Ki Hajar Dewantara pepatah ini sangat tepat yaitu "educate the head, the heart, and the hand".

Guru yang efektif memiliki keunggulan dalam mengajar (fasilitator); dalam hubungan (relasi dan komunikasi) dengan peserta didik dan anggota komunitas sekolah; dan juga relasi dan komunikasinya dengan pihak lain (orang tua, komite sekolah, pihak terkait); segi administrasi sebagai guru; dan sikap profesionalitasnya. Sikap-sikap profesional itu meliputi antara lain: keinginan untuk memperbaiki diri dan keinginan untuk mengikuti perkembangan zaman. Maka penting pula membangun suatu etos kerja yang positif yaitu: menjunjung tinggi pekerjaan; menjaga harga diri dalam melaksanakan pekerjaan, dan keinginan untuk melayani masyarakat. Dalam kaitan dengan ini penting juga performance/penampilan seorang profesional: secara fisik, intelektual, relasi sosial, kepribadian, nilai-nilai dan kerohanian serta mampu menjadi motivator. Singkatnya perlu adanya peningkatan mutu kinerja yang profesional, produktif dan kolaboratif demi pemanusiaan secara utuh setiap peserta didik.

\section{Implikasi Filosofi Pendidikan Ki Hajar Dewantara}

Dasar yang paling penting dalam pendidikan menurut Ki Hajar Dewantara adalah adanya persamaan persepsi antara penegak atau pemimpin pendidikan tentang arti "mendidik" itu sendiri. Beliau menyatakan bahwa mendidik itu bersifat humanisasi, yakni mendidik adalah proses memanusiakan manusia dengan adanya pendidikan diharapkan derajat hidup manusia bisa bergerak vertikal ke atas ke taraf insani yang lebih baik dari sebelumnya. Dalam konsep pendidikan Ki Hajar Dewantara ada dua hal yang harus dibedakan yaitu, "Pengajaran" dan "Pendidikan" yang harus bersinergis satu sama lain. Adapun menurut beliau pengajaran bersifat memerdekakan manusia dari aspek hidup lahiriah (kemiskinan dan kebodohan). Sedangkan pendidikan mengarah pada memerdekakan manusia dari aspek hidup batin (otonomi berpikir dan mengambil keputusan, martabat, mentalitas demokratik). Jadi jelaslah bahwa manusia yang merdeka adalah manusia yang hidupnya secara lahir dan batin tidak terganggu kepada orang lain, akan tetapi ia mampu bersandar dan berdiri di atas kakinya sendiri. Artinya sistem pendidikan itu mampu menjadikan setiap individu hidup mandiri dan berpikir sendiri.

Ki Hadjar Dewantara mengatakan bahwa; Pendidikan ialah usaha kebudayaan yang bermaksud memberi bimbingan dalam hidup tumbuhnya jiwa raga anak agar dalam kodrat pribadinya serta pengaruh lingkunganannya, mereka memperoleh kemajuan lahir batin menuju ke arah adab kemanusiaan (Ki Suratman, 1987: 12). Sedang yang dimaksud adab kemanusiaan adalah tingkatan tertinggi yang dapat dicapai oleh manusia yang berkembang selama hidupnya. Artinya dalam upaya mencapai kepribadian seseorang atau karakter seseorang, maka adab kemanusiaan adalah tingkat yang tertinggi. Dari definisi pendidikan tersebut terdapat dua kalimat kunci yaitu; „tumbuhnya jiwa raga anak" dan „, kemajuan anak lahir-batin". Dari dua kalimat kunci 
tersebut dapat dimaknai bahwa manusia bereksistensi ragawi dan rokhani atau berwujud raga dan jiwa. Adapun pengertian jiwa dalam budaya bangsa meliputi "ngerti, ngrasa, lan nglakoni" (cipta, rasa, dan karsa). Kalau digunakan dalam istilah psikologi, ada kesesuaiannya dengan aspek atau domain kognitif, domain emosi, dan domain psikomotorik atau konatif.

Ki Hadjar Dewantara lebih lanjut menegaskan bahwa pendidikan itu suatu tuntunan dalam hidup tumbuhnya anak-anak. Ini berarti bahwa hidup tumbuhnya anak-anak itu terletak di luar kecakapan atau kehendak para pendidik. Anak itu sebagai makhluk, sebagai manusia, sebagai benda hidup teranglah hidup dan tumbuh menurut kodratnya sendiri. Seperti yang termaktub di muka, maka apa yang dikatakan kekuatan kodrati yang ada pada anak itu tidak lain ialah segala kekuatan di dalam hidup batin dan hidup lahir dari anak-anak itu, yang ada karena kekuatan kodrat. Kaum pendidik hanya dapat menuntun tumbuhnya atau hidupnya kekuatankekuatan itu, agar dapat memperbaiki lakunya (bukan dasarnya) hidup dan tumbuhnya itu.

Dari konsepsi tersebut dapat diambil kesimpulan bahwa Ki Hadjar Dewantara ingin; a) menempatkan anak didik sebagai pusat pendidikan, b) memandang pendidikan sebagai suatu proses yang dengan demikian bersifat dinamis, dan c) mengutamakan keseimbangan antar cipta, rasa, dan karsa dalam diri anak. Dengan demikian pendidikan yang dimaksud oleh Ki Hadjar Dewantara memperhatikan keseimbangan cipta, rasa, dan karsa tidak hanya sekedar proses alih ilmu pengetahuan saja atau transfer of knowledge, tetapi sekaligus pendidikan juga sebagai proses transformasi nilai (transformation of value). Dengan kata lain pendidikan adalah proses pembetukan karakter manusia agar menjadi sebenar-benar manusia.

Dalam proses tumbuh kembangnya seorang anak, Ki Hadjar Dewantara memandang adanya tiga pusat pendidikan yang memiliki peranan besar. Semua ini disebut "Tripusat Pendidikan". Tripusat Pendidikan mengakui adanya pusat-pusat pendidikan yaitu; 1) Pendidikan di lingkungan keluarga, 2) Pendidikan di lingkungan perguruan, dan 3) Pendidikan di lingkungan kemasyarakatan atau alam pemuda. Alam keluarga adalah pusat pendidikan yang pertama dan terpenting. Sejak timbul adab kemanusiaan hingga kini, hidup keluarga selalu mempengaruhi bertumbuhnya budi pekerti atau karakter dari tiap-tiap manusia. Alam perguruan merupakan pusat perguruan yang teristimewa berkewajiban mengusahakan kecerdasan pikiran (perkembangan intelektual) beserta pemberian ilmu pengetahuan (balai-wiyata). Alam kemasyarakatan atau alam pemuda merupakan kancah pemuda untuk beraktivitas dan beraktualisasi diri mengembangkan potensi dirinya. Ketiga lingkungan pendidikan tersebut sangat erat kaitannya satu dengan lainnya, sehingga tidak bisa dipisah-pisahkan, dan memerlukan kerjasama yang sebaik-baiknya, untuk memperoleh hasil pendidikan maksimal seperti yang dicita-citakan. Hubungan sekolah (perguruan) dengan rumah anak didik sangat erat, sehingga berlangsungnya pendidikan terhadap anak selalu dapat diikuti serta diamati, agar dapat berjalan sesuai dengan tujuan yang hendak dicapai. Pamong sebagai pimpinan harus bertindak tutwuri handayani, ing madya mangun karsa, dan ing ngarsa sung tuladha yaitu; mengikuti dari belakang dan memberi pengaruh, berada di tengah memberi semangat, berada di depan menjadi teladan.

Selain tripusat pendidikan Ki Hadjar Dewantara mengemukakan ajaran Trikon. Teori Trikon merupakan usaha pembinaan kebudayaan nasional yang mengandung tiga unsur yaitu kontinuitas, konsentrisitas, dan konvergensi.

\section{a. Dasar Kontinuitas}

Dasar kontinuitas berarti bahwa budaya, kebudayaan atau garis hidup bangsa itu sifatnya kontinu, bersambung tak putus-putus. Dengan perkembangan dan kemajuan kebudayaan, garis hidup bangsa terus menerima pengaruh nilai-nilai baru, garis kemajuan suatu bangsa ditarik terus. Bukan loncatan terputus-putus dari garis asalnya. Loncatan putus-putus akan kehilangan pegangan. Kemajuan suatu bangsa ialah lanjutan dari garis hidup asalnya, yang ditarik terus dengan menerima nilai-nilai baru dari perkembangan sendiri maupun dari luar. Jadi kontinuitas dapat diartikan bahwa dalam mengembangkan dan membina karakter bangsa harus merupakan kelanjutan dari budaya sendiri.

\section{b. Dasar Konsentris}

Dasar konsentris berarti bahwa dalam mengembangkan kebudayaan harus bersikap terbuka, namun kritis dan selektif terhadap pengaruh kebudayaan di sekitar kita. Hanya unsurunsur yang dapat memperkaya dan mempertinggi mutu kebudayaan saja yang dapat diambil dan diterima, setelah dicerna dan disesuaikan dengan kepribadian bangsa. Hal ini merekomendasikan bahwa pembentukan karakter harus berakar pada budaya bangsa, meskipun 
tidak tertutup kemungkinan untuk mengakomodir budaya luar yang baik dan selaras dengan budaya bangsa.

\section{c. Dasar Konvergensi}

Dasar konvergensi mempunyai arti bahwa dalam membina karakter bangsa, bersamasama bangsa lain diusahakan terbinanya karakter dunia sebagai kebudayaan kesatuan umat sedunia (konvergen), tanpa mengorbankan kepribadian atau identitas bangsa masing-masing. Kekhususan kebudayaan bangsa Indonesia tidak harus ditiadakan, demi membangun kebudayaan dunia.

Dari pernyataan di atas dapat diambil kesimpulan bahwa dalam mengembangkan karakter dan membina kebudayaan bangsa harus merupakan kelanjutan dari budaya sendiri (kontinuitas) menuju ke arah kesatuan kebudayaan dunia (konvergensi), dan tetap terus memiliki dan membina sifat kepribadian di dalam lingkungan kemanusiaan sedunia (konsentrisitas). Dengan demikian maka pengaruh terhadap kebudayaan yang masuk, harus bersikap terbuka, disertai sikap selektif sehingga tidak menghilangkan identitas sendiri.

Dalam pelaksanaan pendidikan, Ki Hadjar Dewantara menggunakan "Sistem Among" sebagai perwujudan konsepsi beliau dalam menempatkan anak sebagai sentral proses pendidikan. Dalam Sistem Among, maka setiap pamong sebagai pemimpin dalam proses pendidikan diwajibkan bersikap: Ing ngarsa sung tuladha, Ing madya mangun karsa, dan Tutwuri handayani (MLPTS, 1992: 19-20).

\section{a. Ing Ngarsa Sung Tuladha}

Ing ngarsa berarti di depan, atau orang yang lebih berpengalaman dan atau lebih berpengatahuan. Sedangkan tuladha berarti memberi contoh, memberi teladan (Ki Muchammad Said Reksohadiprodjo, 1989: 47). Jadi ing ngarsa sung tuladha mengandung makna, sebagai pendidik adalah orang yang lebih berpengetahuan dan berpengalaman, hendaknya mampu menjadi contoh yang baik atau dapat dijadikan sebagai "central figure" bagi siswa (Among).

\section{b. Ing Madya Mangun Karsa}

Mangun karsa berarti membina kehendak, kemauan dan hasrat untuk mengabdikan diri kepada kepentingan umum, kepada cita-cita yang luhur. Sedangkan ing madya berarti di tengahtengah, yang berarti dalam pergaulan dan hubungannya sehari-hari secara harmonis dan terbuka. Jadi ing madya mangun karsa mengandung makna bahwa pamong atau pendidik sebagai pemimpin hendaknya mampu menumbuhkembangkan minat, hasrat dan kemauan anak didik untuk dapat kreatif dan berkarya, guna mengabdikan diri kepada cita-cita yang luhur dan ideal (Momong)

\section{c. Tutwuri Handayani}

Tutwuri berarti mengikuti dari belakang dengan penuh perhatian dan penuh tanggung jawab berdasarkan cinta dan kasih sayang yang bebas dari pamrih dan jauh dari sifat authoritative, possessive, protective dan permissive yang sewenang-wenang. Sedangkan handayani berarti memberi kebebasan, kesempatan dengan perhatian dan bimbingan yang memungkinkan anak didik atas inisiatif sendiri dan pengalaman sendiri, supaya mereka berkembang menurut garis kodrat pribadinya (Ngemong).

Cara mendidik menurut Ki Hadjar Dewantara disebutnya sebagai "peralatan pendidikan". Menurut Ki Hadjar Dewantara cara mendidik itu amat banyak, tetapi terdapat beberapa cara yng patut diperhatikan, yaitu (a). Memberi contoh (voorbeelt), (b). Pembiasaan (pakulinan, gewoontevorming), (c). Pengajaran (wulang-wuruk), (d). Laku (zelfbeheersching), €. Pengalaman lahir dan batin (nglakoni, ngrasa) (Ki Hadjar Dewantara dalam Majelis Luhur Persatuan Tamansiswa, 1977: 28).

\section{Simpulan dan Saran}

Bertolak dari paparan di atas, maka dapat disimpulkan hal-hal sebagai berikut. (1) Dilatarbelakangi oleh dorongan heroik terlepas dari pusaran tirani penjajahan Belanda, telah mendorong Ki Hajar Dewantara untuk memaknai pendidikan secara filosofi sebagai upaya memerdekakan manusia dalam aspek lahiriah (kemiskinan dan kebodohan), dan batiniah (otonomi berpikir dan mengambil keputusan, martabat, mentalitas demokratik); (2) Filosofi 
pendidikan Ki Hajar Dewantara bersendikan pada tiga pilar pemikiran pendidikan, yakni Ing ngarsa sung tuladha, Ing madya mangun karsa, dan Tutwuri handayani, kemudian dijawantahkan dalam sistem among, momong, ngemong dalam proses pembelajaran; dan (3) Bertolak dari filosofi pendidikan Ki Hajar Dewantara maka pendidikan harus menjamin terjadinya proses transformasi knowledge menuju proses transformasi nilai (value). Berkaitan dengan hal ini, maka disarankan kepada penulis lainya untuk menggali lebih mendalam lagi mengenai tokoh Ki Hajar Dewantara sebagai tokoh pendidikan yang sangat berjasa mengembangkan pendidikan di Indonesia pada zamannya.

\section{Daftar Pustaka}

Darsiti Suratman. Ki Hadjar Dewantara. Jakarta: Majelis Pendidikan dan Kebudayaan. 1985.

Helena Asri Sinawang. 2008. Guru dan Watak Bangsa, dari http://www.keyanaku.blogspot.com. Diunduh 28 Maret 2011.

Irna H.N. Hadi Soewito. Soewardi Soerjaningrat dalam Pengasingan. Jakarta: Balai Pustaka. 1985.

Ki Gunawan. Aktualisasi konsep pendidikan Ki Hadjar Dewantara dalam sistem pendidikan nasional Indonesia di Gerbang XXI, dalam Ki hadjar Dewantara dalam pandangan para cantrik dan mantriknya. Yogyakarta: MLPTS. 1989.

Ki Hadjar Dewantara. Bagian Pertama: Pendidikan. Yogyakarta: Majelis Luhur Persatuan Taman Siswa. 1977.

Ki Muchammad Said Reksohadiprodjo. Masalah-masalah Pendidikan Nasional. Jakarta: CV. Haji Masagung. 1989.

Ki Suratman. Pokok-pokok Ketamansiswaan. Yogyakarta: Majelis Luhur Persatuan Taman Siswa. 1987.

MLPTS. Peraturan Besar dan Piagam Persatuan Taman Siswa. Yogyakarta: MLPTS. 1992.

Muchammad Tauchid. Perjuangan dan Ajaran Hidup Ki Hadjar Dewantara. Yogyakarta: Majelis Luhur Persatuan Taman Siswa. 1963.

Muchammad Tauchid dan Ki Suratman. Taman Siswa dan Sila Ketuhanan Yang Maha Esa. Yogyakarta: MLPTS. 1988.

Winarno Surakhmad, dkk. (2003). Mengurai Benang Kusut Pendidikan. Jakarta: Transformasi. 